\title{
Asymmetric Total Synthesis of Soraphen A: a Flexible Alkyne Strategy**
}

\author{
Barry M. Trost ${ }^{\star}$, Joshua D. Sieber, Wei Qian, Rajiv Dhawan, and Zachary T. Ball \\ Department of Chemistry, Stanford University, Stanford, CA 94305, (USA)
}

\begin{abstract}
The alkyne functional group can be a valuable handle for organic synthesis since the alkyne can function both as a nucleophile or as an electrophile when activated with an appropriate metal catalyst. Herein, we exploit this dual nature of the alkyne moiety for the concise total synthesis of the natural product soraphen A.
\end{abstract}

\section{Keywords}

alkynes; asymmetric synthesis; macrolactones; natural products; total synthesis

Soraphen A (1, Scheme 1) is a complex polyketide natural product discovered in 1986 when it was isolated from the soil bacterium Sorangium cellulosum by Höfle and coworkers. ${ }^{[1]}$ Importantly, $\mathbf{1}$ is a potent antifungal agent possessing activity against a broad spectrum of fungi. ${ }^{[2]}$ Furthermore, the antifungal activity of 1 results from a unique mode of action, whereby selective inhibition of the acetyl-CoA carboxylase (ACC) enzyme of the fungus results in cell death by disruption of lipid synthesis in the cell. ${ }^{[3]}$ As a result, $\mathbf{1}$ has the potential for application in the treatment of obesity, diabetes, ${ }^{[4]}$ and cancer. ${ }^{[5]}$ Structurally, 1 is comprised of an 18-membered macrolactone, including 10 stereocenters and a highly substituted pyranose ring system. These features make $\mathbf{1}$ a challenging target for total synthesis. To date, only one completed total synthesis of $\mathbf{1}$ has been reported by Giese and coworkers. ${ }^{[6]}$ In addition, several groups have reported their efforts towards the synthesis of 1. $^{[7]}$ Herein we report our asymmetric total synthesis of $\mathbf{1}$ that relies on the versatility of the alkyne functional group to provide a concise route to $\mathbf{1}$.

\begin{abstract}
Alkynes are versatile functional groups because they can be used both as nucleophiles by deprotonation of a terminal alkyne and as electrophiles ${ }^{[8]}$ by activation of the alkyne with a transition metal. Our retrosynthetic plan (Scheme 1) was devised around this concept of using the dual nature of the alkyne moiety to provide a concise synthesis of the target. Accordingly, the $\mathrm{C} 10-\mathrm{C} 11$ bond could arise from a Felkin-selective acetylide addition of alkyne $\mathbf{3}$ to aldehyde $\mathbf{2}$. Subsequent treatment of the resultant internal alkyne in a hydrosilylation/protodesilylation ${ }^{[9]}$ sequence should conveniently allow for reduction of the alkyne to the requisite C9-C10 trans olefin present in $\mathbf{1}$. The completion of $\mathbf{1}$ was then envisioned to arise from a late stage macrolactonization. ${ }^{[10]}$
\end{abstract}

\footnotetext{
** We thank the National Institute of Health (GM13598) for their generous support of our program, and S. Lynch for assistance with NMR pectroscopy. JDS thanks the American Cancer Society for a post-doctoral fellowship. We gratefully thank Johnson and Matthey for donation of precious metal salts, and Aldrich Chemical Co. for donation of $(S, S)-\mathbf{8}$.

${ }^{[*}$ Fax: (+1) 650-725-0002, bmtrost@stanford.edu, Homepage: http://www.stanford.edu/group/bmtrost/.

Supporting information for this article is available on the WWW under http://www.angewandte.org or from the author.
} 
The hemiketal portion of $\mathbf{1}$ was envisioned to arise from treatment of ketone $\mathbf{3}\left(\mathrm{R}^{2}=\mathrm{H}\right)$ with acid. The a-alkoxyketone 3 was then proposed to arise from oxidation of epoxysilane 4 . We have previously demonstrated the utility of epoxysilanes as masked a-hydroxyketones, wherein Tamao-Fleming oxidation of the epoxysilane conveniently unmasks this group. ${ }^{[11]}$ Furthermore, these epoxysilanes are readily prepared from an alkyne functional group by hydrosilylation followed by epoxidation. Thus, an alkyne serves as a convenient synthon for an a-hydroxyketone facilitating $\mathrm{C}-\mathrm{C}$ bond formation and minimizing the use of protecting groups. Installation of the requisite stereochemistry at C6 and C7 in $\mathbf{4}$ could arise from a substrate controlled diastereoselective aldol between ketone $\mathbf{6}$ and aldehyde $\mathbf{7}$ while forming the C6-C7 bond. Finally, aldehyde 2 was envisioned to arise from alkyne 5 by a catalyst controlled acetylide addition of the alkyne to benzaldehyde using the dinuclear zinc catalyst system $^{[12]}$ developed in our laboratory. Furthermore, alkyne $\mathbf{5}$ in turn derives from an epoxide opening with a terminal alkyne as well. Both terminal alkynes have their origin in 1-propyne where it serves as a lynchpin. After utilizing the terminal alkyne of 1-propyne as a nucleophile, zipping ${ }^{[13]}$ it recreates a new terminal alkyne to repeat its functioning as a new nucleophile. This reactivity profile provides two strategies for controlling absolute stereochemistry: use of the chiral pool and catalyst controlled asymmetric induction.

Synthesis of the aldehyde fragment began with the preparation of alkyne 5 in 3 steps from (S)-glycidol (Scheme 2). Epoxide opening with the Li-acetylide of propyne, followed by isomerization of the internal alkyne to the terminal position using potassium 3aminopropylamide, ${ }^{[13]}$ and TBS protection of the diol gave $\mathbf{5}$. Coupling of $\mathbf{5}$ and benzaldehyde using $10 \mathrm{~mol} \%(S, S)-8$ as ligand furnished the desired propargylic alcohol 9 in excellent yield and diastereoselectivity. Exhaustive reduction of the alkyne to the alkane using Adams' catalyst ${ }^{[14]}$ proceeded in excellent yield with minimal reduction of the benzylic alcohol as is often observed when using Pd/C as catalyst. ${ }^{[5]}$ The benzylic secondary alcohol was then protected as a PMB ether followed by selective deprotection of the primary TBS ether using HF - pyr. Finally, Moffatt-Swern oxidation provided aldehyde 10 in excellent yield.

The alkyne fragment was prepared starting from 4-heptyn-3-ol (11, Scheme 3). Oxidation followed by hydrosilylation afforded ketone $\mathbf{6}$. At this point, attempts at a chelationcontrolled diastereoselective aldol between ketone $\mathbf{6}$ and aldehyde ${ }^{[16]} \mathbf{7}$ was examined. Classical metal-enolate aldols using the enolate generated from LDA or by soft enolization techniques $\left(\mathrm{TiCl}_{4} / \mathrm{NR}_{3}\right)$ were futile and led to decomposition of $\mathbf{6}$ along with recovery of $\mathbf{7}$. Turning to a Mukaiyama aldol process, deprotonation of $\mathbf{6}$ with LDA followed by trapping with TMSCl allowed for the synthesis of silyl enol ether 12 as a $\sim 1: 1$ mixture of $E$ - and $Z$ isomers. Since the diastereoselectivity of some Mukaiyama aldol reactions have been shown to be independent of silyl enol ether geometry, presumably due to the involvement of open transition states, ${ }^{[17]}$ the mixture of enols (12) was subjected to these types of conditions. Gratifyingly, the use of $\mathrm{TiCl}_{4}$ as Lewis acid furnished the $s y n$ aldol adduct 13. Subsequent 1,3-syn reduction of enone $\mathbf{1 3},{ }^{[18]}$ followed by alcohol directed epoxidation of the vinyl silane, and protection of the 1,3-diol allowed for stereoselective synthesis of epoxysilane $\mathbf{1 4}$. Finally, the terminal alkyne was installed by hydrogenolysis of the primary benzyl ether, followed by Moffatt-Swern oxidation of the primary alcohol, and conversion to the alkyne using the Ohira-Bestmann reagent. ${ }^{[19]}$

With aldehyde $\mathbf{1 0}$ and alkyne $\mathbf{1 5}$ in hand, conditions for joining the two fragments via a Felkin-controlled metal acetylide addition were explored (Scheme 4). Interestingly, use of the alkynyl titanate of $\mathbf{1 5}$ (not shown) gave the product of formal chelation-controlled addition in good diastereoselectivity $(9: 1 \mathrm{dr})$ despite the tendency of these reagents to give good Felkin-controlled addition. ${ }^{[20]}$ Only the lithium acetylide of $\mathbf{1 5}$ was found to slightly favor the Felkin addition product (16). Various additives that are potential $\mathrm{Li}$-atom chelators 
were examined with the hypothesis that this chelation may increase the steric bulk of the Liacetylide and thereby increase the selectivity for the Felkin product. Ultimately, use of TMEDA as an additive led to the formation of $\mathbf{1 6}$ in 4.8:1 dr and excellent yield. However, the diastereomers could not be separated at this point, and the mixture was carried forward.

With access to 16, we turned our attention to Tamao-Fleming ${ }^{[21]}$ oxidation of the epoxysilane moiety of $\mathbf{1 6}$ to unmask the a-hydroxyketone. First, the secondary alcohol was methylated with Meerwein's salt, and Tamao-Fleming oxidation was then explored. The use of aqueous $\mathrm{H}_{2} \mathrm{O}_{2}$, under conditions first reported by Hosomi and coworkers ${ }^{[22]}$ that we have previously exploited for this transformation, ${ }^{[11]}$ led to substantial amounts of protodesilylation. However, under anhydrous conditions developed in our laboratory, ${ }^{[11]}$ using urea hydrogen peroxide complex (UHP) as oxidant, clean oxidation was observed in good yield with only small amounts of protodesilylation (ca 10-15\%). The secondary TBS ether was not deprotected during the oxidation, and subsequent deprotection was achieved using HF.pyr to afford 17.

Synthesis of the C9-C10 trans olefin by hydrosilylation/protodesilylation of the internal alkyne of $\mathbf{1 7}$ was next examined. Silylation of the secondary alcohols of $\mathbf{1 7}$, followed by hydrosilylation ${ }^{[9]}$ afforded vinylsilane $\mathbf{1 9}$, which was subjected to protodesilylation without purification. A variety of protodesilylation conditions were examined; however, only AgF was successful in this system ${ }^{[23]}$ allowing access to $\mathbf{2 0}$ in good overall yield from 17. It was at this point that the epimeric mixture at $\mathrm{C} 11$ could be separated by chromatography.

To complete the synthesis, formation of the hemiketal portion of $\mathbf{1}$ and macrolactonization was required. Global methylation of the free alcohols in 20, followed by Mander's carboxylation of the enolate formed from kinetic deprotonation of the ketone provided $\mathbf{2 1}$ as an inseparable mixture of epimers at $\mathrm{C} 2$. Heating this mixture in aqueous acetic acid removed the acetonide protecting group and facilitated cyclization furnishing hemiketals 22a and 22b, which were separable by chromatography. Subjection of the incorrect epimer (22a) to basic conditions to allow access to the open form of 22a, followed by treatment with acid to reform the cyclic hemiketal allowed for epimerization of 22a to a $\sim 1.4: 1$ mixture of 22a:22b in 75\% yield. Separation and recycle of 22a allowed for the conversion of 22a to 22b in $53 \%$ overall yield after 3 cycles.

At this point all that remained to complete the synthesis of $\mathbf{1}$ was formation of the macrocycle. Seco-acid $\mathbf{2 3}$ was prepared by initial conversion of hemiketal $\mathbf{2 2 b}$ to the corresponding methyl ketal, followed by removal of the PMB protecting group, and lastly saponification of the methyl ester furnished the desired seco-acid 23. Previous studies by Höfle and coworkers ${ }^{[1 \mathrm{c}]}$ had shown that a related analogue to $\mathbf{2 3}$ bearing a protecting group on the C5 hydroxyl was inert to typical macrolactonization procedures that rely on activation of the carboxylic acid functionality. However, Höfle was able to effect macrolactonization of this system through a four step sequence utilizing activation of the alcohol moiety. While our synthesis is amenable to this approach by protection of the C5 hydroxyl of $\mathbf{2 2 b}$ prior to PMB deprotection and saponification, this route is somewhat cumbersome. Furthermore, it was envisioned that the absence of a protecting group at the C5 hydroxyl might allow for more efficient macrolactonization. Therefore, we chose to examine the viability of directly converting $\mathbf{2 3}$ to the desired macrolactone using this approach. Gratifyingly, macrolactonization of $\mathbf{2 3}$ using Shiina's method ${ }^{[24]}$ furnished the desired macrolactone. Subsequent removal of the methyl ketal ${ }^{[1 \mathrm{c}]}$ afforded synthetic $\mathbf{1}$ whose spectral data was consistent with the natural product.

In conclusion, we have prepared $\mathbf{1}$ in 25 linear and 34 total steps beginning from commercial materials 11, glycidol, and methyl (S)-3-hydroxy-2-methylpropiolate. ${ }^{[16]}$ This synthesis 
further illustrates the versatility of the alkyne functional group in complex molecule synthesis.

\section{Supplementary Material}

Refer to Web version on PubMed Central for supplementary material.

\section{References}

[1]. a) Reichenback H, Höfle G, Augustiniak H, Bedorf N, Forche E, Gerth K, Irschik H, Jansen R, Kunze B, Sasse F, Steinmetz H, Trowitzsch-Kienast W, Pachlatko JP. EP 282455. 1988; A2b) Bedorf N, Schomburg D, Gerth K, Reichenbach H, Höfle G. Liebigs Ann. 1993:1017.c) Schummer D, Jahn T, Höfle G. Liebigs Ann. 1995:803.

[2]. Gerth K, Bedorf N, Irschik H, Höfle G, Reichenbach H. J Antibiot. 1994; 47:23. [PubMed: 8119858]

[3]. Vahlensieck HF, Pridzun L, Reichenbach H, Hinnen A. Curr Genet. 1994; 25:95. [PubMed: 7916271]

[4]. Weatherly SC, Volrath SL, Elich TD. Biochem J. 2004; 380:105. [PubMed: 14766011]

[5]. Beckers A, Organe S, Timmermans L, Scheys K, Peeters A, Brusselmans K, Verhoeven G, Swinnen JV. Cancer Res. 2007; 67:8180. [PubMed: 17804731]

[6]. a) Abel S, Faber D, Hüter O, Giese B. Angew Chem Int Ed. 1994; 33:2466.Angew Chem. 1994; 106:2522.b) Abel S, Faber D, Hüter O, Giese B. Synthesis. 1999:188.

[7]. a) Díaz-Oltra S, Murga J, Falomir E, Carda M, Peris G, Marco JA. J Org Chem. 2005; 70:8130. [PubMed: 16277339] b) Park SH, Lee HW, Park S-U. Bull Korean Chem Soc. 2004; 25:1613.c) Lee HW, Lee I-YC, Kim Y-S, Park S-U. Bull Korean Chem Soc. 200223:1197.d) Gurjar MK, Mainkar AS, Srinivas P. Tetrahedron Lett. 1995; 36:5967.e) Loubinoux B, Sinnes J-L, O’Sullivan AC, Winkler T. Helv Chim Acta. 1995; 78:122.f) Loubinoux B, Sinnes J-L, O’Sullivan AC, Winkler T. J Org Chem. 1995; 60:953.g) Cao Y, Eweas AF, Donaldson WA. Tetrahedron Lett. 2002; 43:7831.h) Lee HW, Kim YJ. Bull Korean Chem Soc. 1996; 17:1107.i) Vincent G, Mansfield DJ, Vors J-P, Ciufolini MA. Org Lett. 2006; 8:2791. [PubMed: 16774258] j) Park SH, Lee HW. Bull Korean Chem Soc. 2008; 29:1445.k) Eweas AH. Synth Commun. 2008; 38:1541.

[8]. Stang, PJ.; Diederich, F., editors. Modern Acetylene Chemistry. WILEY-VCH; Weinheim: 1995.

[9]. a) Trost BM, Ball ZT, Jöge T. J Am Chem Soc. 2002; 124:7922. [PubMed: 12095335] b) Trost BM, Ball ZT. J Am Chem Soc. 2005; 127:17644. [PubMed: 16351094] c) Trost BM, Ball ZT. J Am Chem Soc. 2003; 125:30. [PubMed: 12515496]

[10]. Review:Parenty A, Moreau X, Campagne J-M. Chem Rev. 2006; 106:911. [PubMed: 16522013]

[11]. Trost BM, Ball ZT, Laemmerhold KM. J Am Chem Soc. 2005; 127:10028. [PubMed: 16011365]

[12]. Trost BM, Weiss AH, Jacobi von Wangelin A. J Am Chem Soc. 2006; 128:8. [PubMed: 16390095]

[13]. a) Brown CA, Yamashita A. J Am Chem Soc. 1975; 97:891.b) Macaulay SR. J Org Chem. 1980; 45:734.c) Abrams SR, Shaw AC. Organic Syntheses. 1988; 66:127.

[14]. Voorhees V, Adams R. J Am Chem Soc. 1922; 44:1397.

[15]. Entwistle, ID.; Wood, WD. Comprehensive Organic Synthesis. Fleming, I.; Trost, BM., editors. Vol. 8. Pergamon Press; New York: 1991. p. 955-981.

[16]. Aldehyde 7 was prepared from methyl $(S)-(+)-3$-hydroxy-2-methylpropiolate in $67 \%$ overall yield, see supporting information.

[17]. a) Gennari C, Beretta MG, Bernardi A, Moro G, Scolastico C, Todeschini R. Tetrahedron. 1986; 42:893.b) Heathcock CH, Davidsen SK, Hug KT, Flippin LA. J Org Chem. 1986; 51:3027.

[18]. a) Chen K-M, Hardtmann GE, Prasad K, Repiĉ O, Shapiro MJ. Tetrahedron Lett. 1987; 28:155.b) Hoveyda AH, Evans DA, Fu GC. Chem Rev. 1993; 93:1307.c) Tempkin O, Abel S, Chen C-P, Underwood R, Prasad K, Chen K-M, Repic O, Blacklock TJ. Tetrahedron. 1997; 53:10659.

[19]. Muller S, Liepold B, Roth GJ, Bestmann HJ. Synlett. 1996:521. 
[20]. Guillarme S, Plé K, Banchet A, Liard A, Haudrechy A. Chem Rev. 2006; 106:2355. [PubMed: 16771453]

[21]. a) Tamao K, Akita M, Kumada M. J Organomet Chem. 1983; 254:13.b) Tamao K, Kumada M, Maeda K. Tetrahedron Lett. 1984; 25:321.c) Fleming I, Henning R, Parker DC, Plaut HE, Sanderson PEJ. J Chem Soc, Perkin Trans 1. 1995:317.d) Review: Jones GR, Landais Y. Tetrahedron. 1996; 52:7599.

[22]. a) Miura K, Hondo T, Takahashi T, Hosomi A. Tetrahedron Lett. 2000; 41:2129.b) Miura K, Hondo T, Nakagawa T, Takahasi T, Hosomi A. Org Lett. 2000; 2:385. [PubMed: 10814329]

[23]. Fürstner A, Radkowski K. Chem Commun. 2002:2182.

[24]. Shiina I, Kubota M, Oshiumi H, Hashizume M. J Org Chem. 2004; 69:1822. [PubMed: 15058924] 


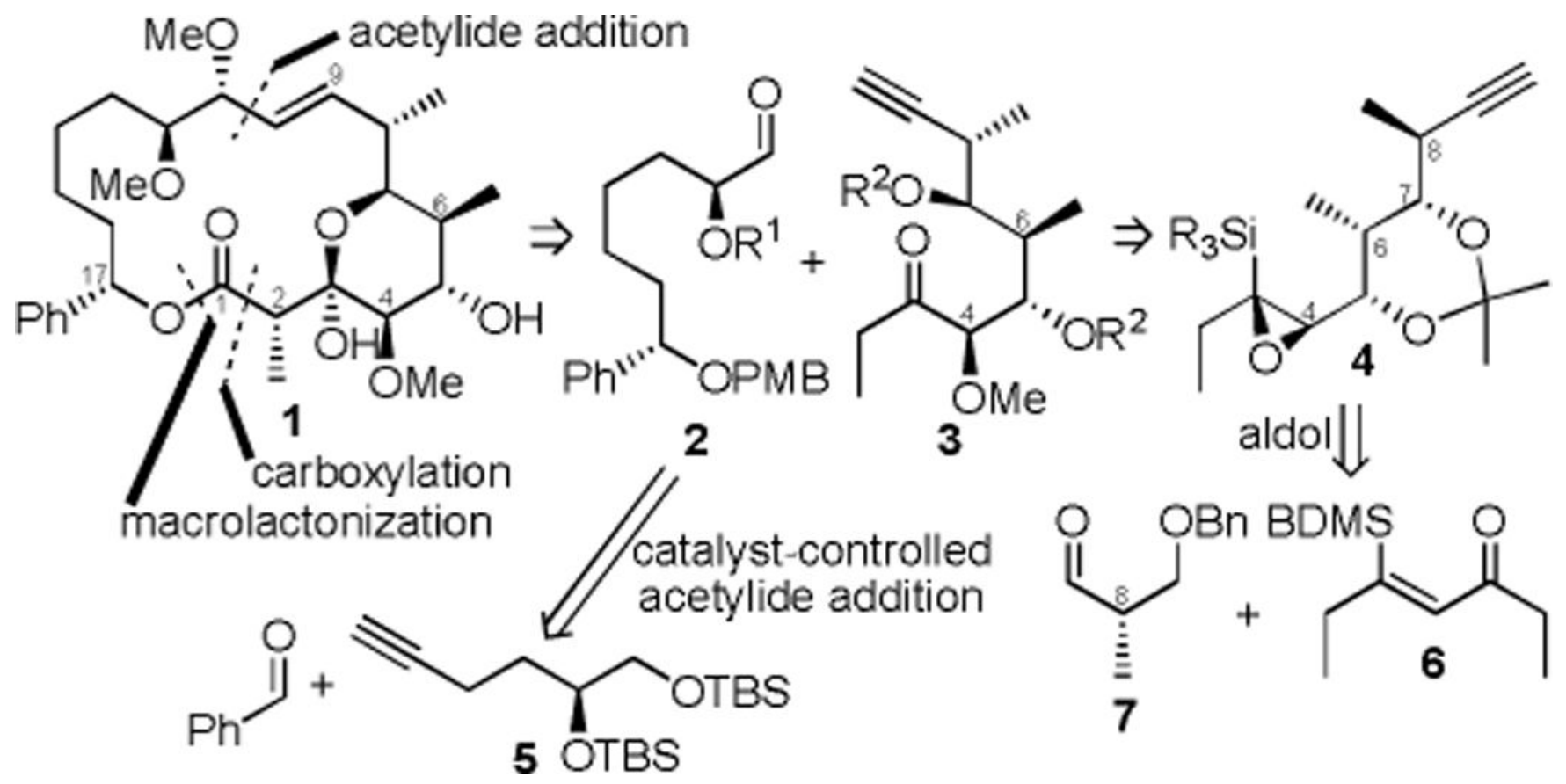

Scheme 1.

Retrosynthetic analysis. PMB = para-methoxybenzyl, TBS = tert-butyldimethylsilyl, BDMS = benzyldimethylsilyl, $\mathrm{Bn}=$ benzyl. 


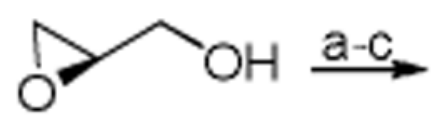

(S)-glycidol

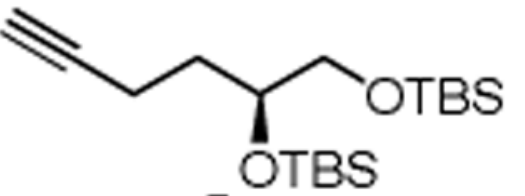

5

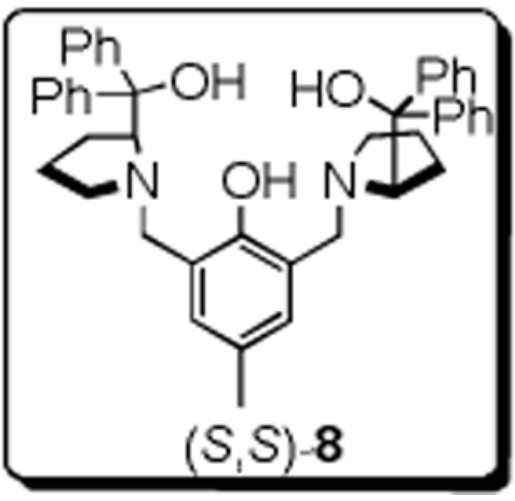

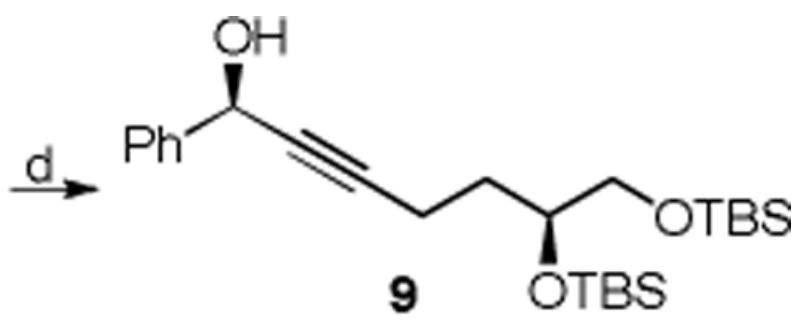

9 OTBS

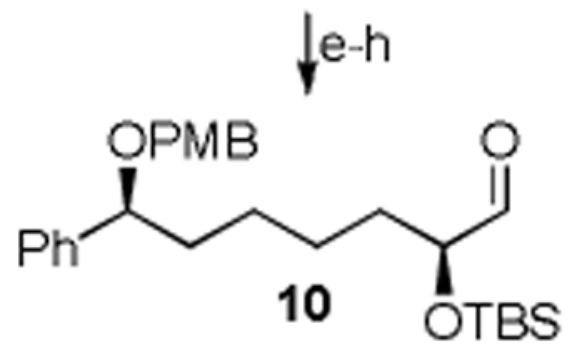

Scheme 2.

Synthesis of the aldehyde fragment. a) propyne, $n$-BuLi, THF/DMPU $(10 / 1),-78{ }^{\circ} \mathrm{C}$ to RT, $20 \mathrm{~h}, 68 \%$; b) 1,3-diaminopropane, $\mathrm{Li}, \mathrm{KO} t \mathrm{Bu}, 66 \%$; c) TBSCl, imidazole, $\mathrm{DMF}, 0{ }^{\circ} \mathrm{C}$ to rt, $2 \mathrm{~h}, 78 \%$; d) $10 \mathrm{~mol} \%(S, S)-8$, benzaldehyde, $\mathbf{5}, \mathrm{ZnMe}_{2}$, toluene, $4{ }^{\circ} \mathrm{C}, 48 \mathrm{~h}, 88 \%(18: 1 \mathrm{dr})$; e) $\mathrm{H}_{2}(1 \mathrm{~atm}), 5 \mathrm{~mol} \% \mathrm{PtO}_{2} \cdot \mathrm{H}_{2} \mathrm{O}$, EtOAc, RT, $1 \mathrm{~h}, 92 \%$; f) TBAI, KHMDS, PMBCl, THF, rt, $90 \%$; g) HF.pyr, pyr, THF, $50 \%+20 \%$ diol; h) $\mathrm{COCl}_{2}$, DMSO, $\mathrm{Et}_{3} \mathrm{~N}, \mathrm{CH}_{2} \mathrm{Cl}_{2}, 98 \%$. DMPU $=1,3$-dimethyl-3,4,5,6-tetrahydro-2 $(1 H)$-pyrimidinone, $\mathrm{TBSCl}=t$ butyldimethylsilyl chloride, TBAI $=$ tetrabutylammonium iodide, $\mathrm{KHMDS}=$ potassium bis(trimethylsilyl)amide, $\mathrm{PMBCl}=4$-methoxybenzyl chloride, $\mathrm{pyr}=$ pyridine . 


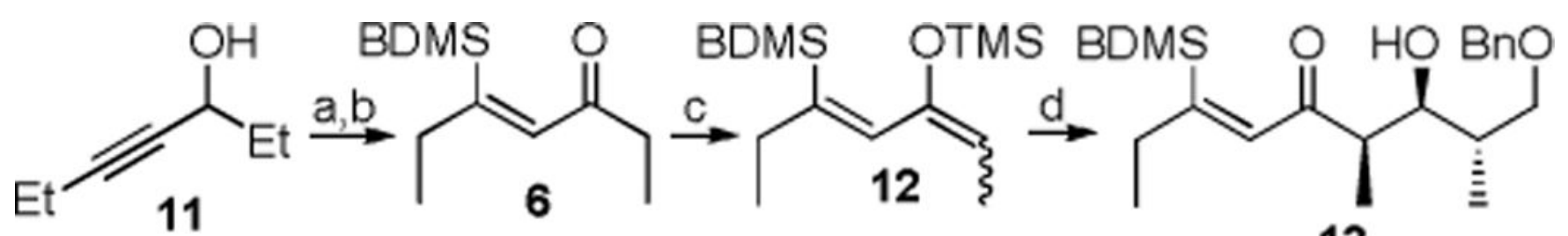<smiles>CCOC(C)C</smiles>

Scheme 3

Synthesis of the alkyne fragment. a) $\mathrm{NaHCO}_{3}, 10 \mathrm{~mol} \% \mathrm{KBr}, 1 \mathrm{~mol} \%$ TEMPO, $\mathrm{NaOCl}$, $\mathrm{RT}, 1 \mathrm{~h}, 75 \%$; b) $0.5 \mathrm{~mol} \%\left[\mathrm{Cp} * \mathrm{Ru}(\mathrm{MeCN})_{3}\right] \mathrm{PF}_{6}$, benzyldimethylsilane, $0{ }^{\circ} \mathrm{C}$ to $\mathrm{RT}, 30$ $\min , 86 \%$; c) LDA, TMSCl, THF, $-78{ }^{\circ} \mathrm{C}$ to RT, > 99\%, 1:1 E:Z; (d) aldehyde 7, $\mathrm{TiCl}_{4}$, $\mathrm{CH}_{2} \mathrm{Cl}_{2},-78{ }^{\circ} \mathrm{C}, 9: 1 \mathrm{dr}, 73 \%$ (yield of major diastereomer); e) $\mathrm{Et}_{2} \mathrm{BOMe}, \mathrm{NaBH}_{4}, \mathrm{THF} /$ $\mathrm{MeOH},-78{ }^{\circ} \mathrm{C}, 4 \mathrm{~h} ; 30 \% \mathrm{H}_{2} \mathrm{O}_{2}, 84 \%$, > 50:1 dr; f) $m-\mathrm{CPBA}, \mathrm{CH}_{2} \mathrm{Cl}_{2},-25^{\circ} \mathrm{C}, 36 \mathrm{~h}, 8: 1 \mathrm{dr}$, $75 \%$ desired epimer; g) 2-methoxypropene, PPTS, $\mathrm{CH}_{2} \mathrm{Cl}_{2}$, RT, 1 h, 82\%; h) $\mathrm{H}_{2}$ (1 atm) 10 wt\% Pd/C, EtOAc, RT, 24 h, 91\%; (i) $(\mathrm{COCl})_{2}$, DMSO, $\mathrm{CH}_{2} \mathrm{Cl}_{2}, \mathrm{Et}_{3} \mathrm{~N}$; dimethyl-1-diazo-2oxopropylphosphonate, NaOMe, THF, $-78{ }^{\circ} \mathrm{C}$ to $-40{ }^{\circ} \mathrm{C}, 81 \%$ over 2 steps. BDMS = benzyldimethylsilyl, $\mathrm{Cp}^{*}=$ pentamethylcyclopentadienyl, TEMPO = 2,2,6,6tetramethylpiperidin-1-yloxyl, LDA = lithium diisopropylamide, $\mathrm{TMSCl}=$ chlorotrimethylsilane, $m$-CPBA $=m$-chloroperbenzoic acid, $\mathrm{PPTS}=$ pyridinium toluenepara-sulfonate. 


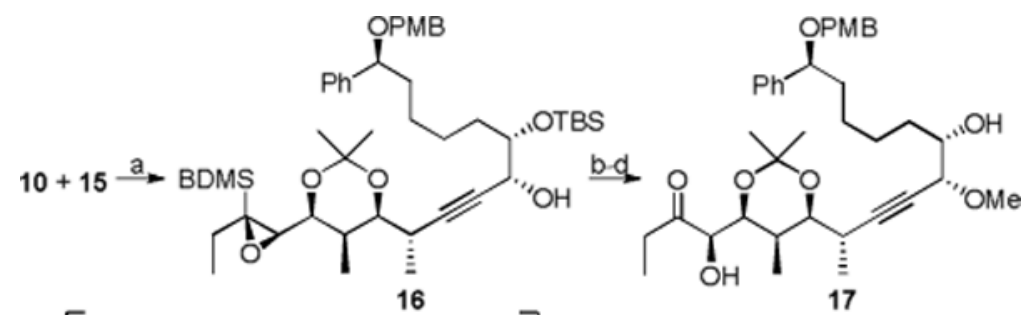

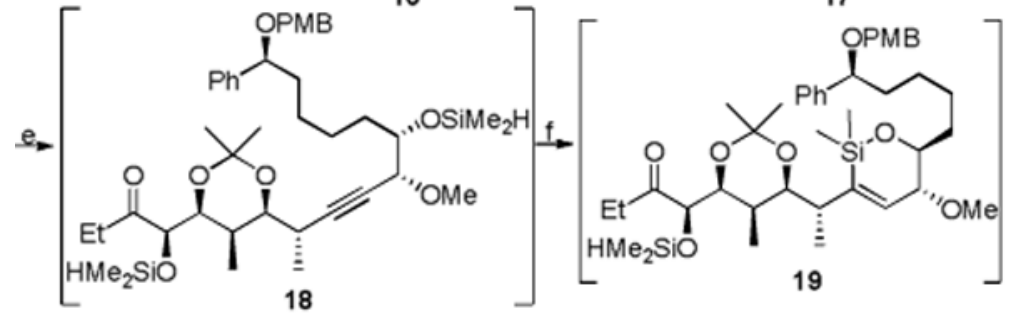

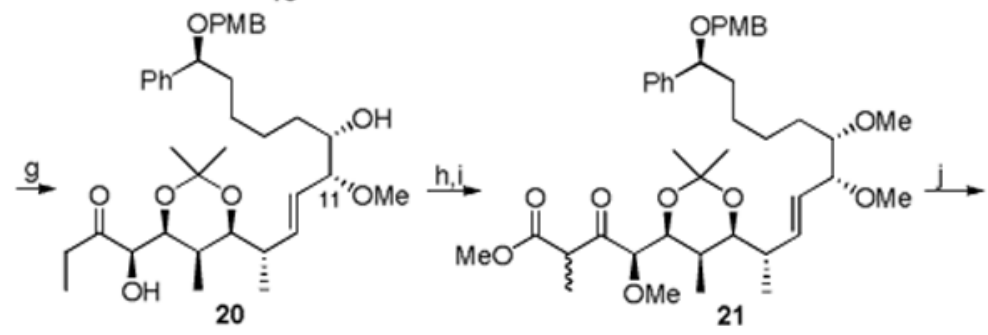

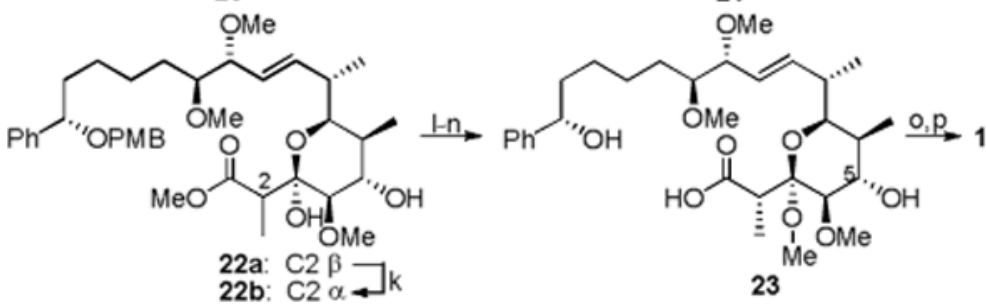

Scheme 4.

Completion of the synthesis. a) TMEDA, $n$-BuLi, THF, $-78{ }^{\circ} \mathrm{C}$ to $-20{ }^{\circ} \mathrm{C}, 92 \%(4.8: 1 \mathrm{dr})$; b) $\mathrm{Me}_{3} \mathrm{OBF}_{4}$, proton sponge, $\mathrm{CH}_{2} \mathrm{Cl}_{2}, \mathrm{RT}, 1.5 \mathrm{~h}, 89 \%$; c) UHP, TBAF (syringe-pump addition), THF, $0{ }^{\circ} \mathrm{C}$ to RT, $2 \mathrm{~h}, 75 \%$; d) HF.pyr, pyr, THF, RT, 48 h, 92\%; e) $\mathrm{NH}\left(\mathrm{SiMe}_{2} \mathrm{H}\right)_{2}$ (neat), $85^{\circ} \mathrm{C}, 3 \mathrm{~h}$; f) $\left.5 \mathrm{~mol} \% \mathrm{CpRu}(\mathrm{MeCN})_{3} \mathrm{PF}_{6}, \mathrm{CH}_{2} \mathrm{Cl}_{2}, \mathrm{RT}, 2 \mathrm{~h} ; \mathrm{g}\right) \mathrm{AgF}$, DMSO, $\mathrm{MeOH}, \mathrm{H}_{2} \mathrm{O}$, THF, RT, $1.5 \mathrm{~h}, 60 \%$ over 3 steps; h) $\mathrm{Me}_{3} \mathrm{OBF}_{4}$, proton sponge, $\mathrm{CH}_{2} \mathrm{Cl}_{2}$, RT, $2 \mathrm{~h}, 88 \%$; i) LDA (4.0 equiv), THF, $-78{ }^{\circ} \mathrm{C}$; then $\mathrm{Et}_{2} \mathrm{O}$, HMPA, methyl cyanoformate, $57-75 \%, 1: 1 \mathrm{dr}$; j) $60 \% \mathrm{AcOH}, 55^{\circ} \mathrm{C}, 3 \mathrm{~h}, 68 \%$; $\left.\mathrm{k}\right) \mathrm{Mg}(\mathrm{OMe})_{2}$, MeOH, RT, $12 \mathrm{~h} ; 60 \% \mathrm{AcOH}, 55^{\circ} \mathrm{C}, 2 \mathrm{~h}, 53 \%$ after 3 cycles; l) amberlyst-15, MeOH, RT, 9 h, 70\%; m) DDQ, pH 7 buffer, $\mathrm{CH}_{2} \mathrm{Cl}_{2}, \mathrm{MeOH}, 4{ }^{\circ} \mathrm{C}, 5 \mathrm{~h}, 80 \%$; n) $\mathrm{Ba}(\mathrm{OH})_{2} \cdot 8 \mathrm{H}_{2} \mathrm{O}, \mathrm{MeOH}, 55^{\circ} \mathrm{C}, 12 \mathrm{~h}$, $75 \%$; o) MNBA, DMAP, toluene, $4 \AA$ MS, syringe-pump addition of $23,17 \mathrm{~h}, 25 \%$; p) $1 \mathrm{M}$ $\mathrm{HCl}$, THF, RT, $25 \mathrm{~min},>99 \%$. TMEDA $=N, N, N^{\prime}, N^{\prime}$-tetramethylethylenediamine, UHP = urea hydrogen peroxide, $\mathrm{TBAF}=$ tetrabutylammonium fluoride, $\mathrm{Cp}=$ cyclopentadienyl, $\mathrm{LDA}=$ lithium diisopropylamide, HMPA = hexamethylphosphoramide, DDQ = 2,3dichloro-5,6-dicyano-para-benzoquinone, MNBA = 2-methyl-6-nitrobenzoic anhydride, DMAP = 4-dimethylaminopyridine, $\mathrm{MS}=$ molecular sieves. 